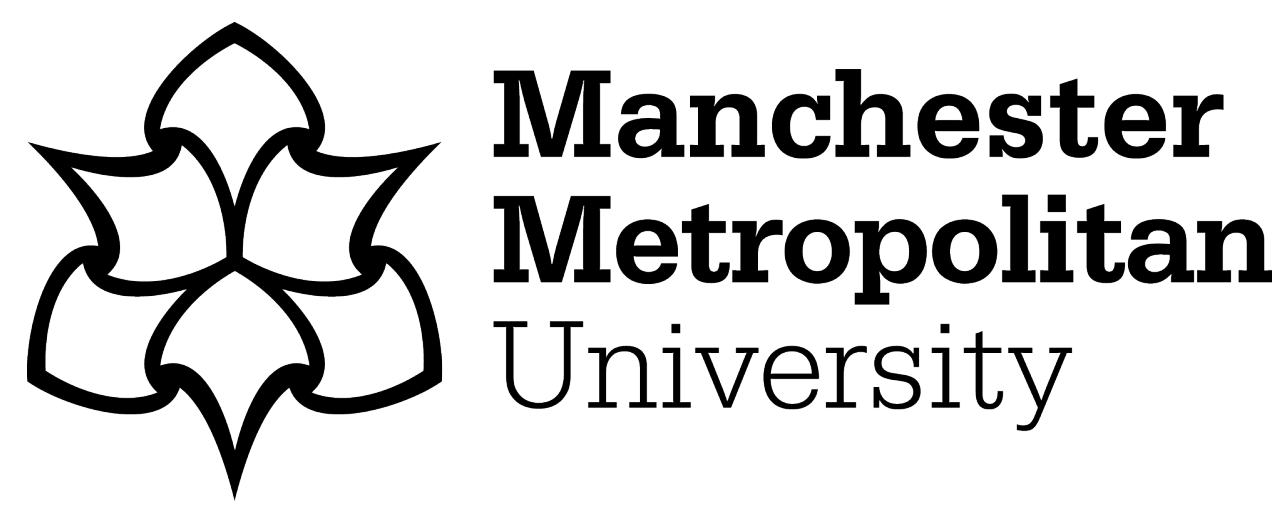

Davies, Julie ORCID logoORCID: https://orcid.org/0000-0002-6875-3100 (2018) Academic-practitioner relationships: developments, complexities and opportunities. Action Learning: Research and Practice, 15 (3). pp. 287-291. ISSN 1476-7333

Downloaded from: https://e-space.mmu.ac.uk/625065/

Version: Accepted Version

Publisher: Taylor \& Francis

DOI: https://doi.org/10.1080/14767333.2018.1510628

Please cite the published version 
See discussions, stats, and author profiles for this publication at: https://www.researchgate.net/publication/327215857

\section{Academic-practitioner relationships: developments, complexities and opportunities}

Article in Action Learning Research and Practice · August 2018

DOI: $10.1080 / 14767333.2018 .1510628$

CITATIONS

0

1 author:

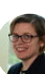

Julie Davies

Manchester Metropolitan University

30 PUBLICATIONS 29 CITATIONS

SEE PROFILE
READS

96

Some of the authors of this publication are also working on these related projects:

Project Data mining and Arctic regional regeneration: A case study of "extreme HRM" in the world's largest greenest data warehouse View project

HE Management View project 


\section{Action Learning: Research and Practice}

\section{Academic-practitioner relationships: developments, complexities and opportunities}

\section{Julie Davies}

To cite this article: Julie Davies (2018) Academic-practitioner relationships: developments, complexities and opportunities, Action Learning: Research and Practice, 15:3, 287-291, DOI: 10.1080/14767333.2018.1510628

To link to this article: https://doi.org/10.1080/14767333.2018.1510628

曲 Published online: 24 Aug 2018.

Submit your article to this journal $\pi$

Џ Article views: 16

View Crossmark data \lceil 
BOOK REVIEWS

Academic-practitioner relationships: developments, complexities and opportunities, edited by Jean M. Bartunek and Jane McKenzie, Abingdon and New York, Routledge, 2018, 331 pp., $£ 105$ (hardback), ISBN 978-1-138-10069-5

Bartunek and McKenzie's co-edited book Academic-Practitioner Relationships provides an inspiring and timely guide for management researchers who collaborate with organizational practitioners. The book includes philosophical reflections on academic-practitioner relationships, candid perspectives on developing appropriate researcher capabilities and interesting cases of successful centres globally. The authors are mainly based in the UK and USA, with additional inputs from France, Ireland and South Africa. Particularly relevant for Action Learning: Research and Practice is MacLean and Maclntosh's chapter on action research and creative action.

In the context of the growing research impact agenda, Academic-Practitioner Relationships draws from Van de Ven's (2007) work on 'engaged scholarship', the Handbook of Collaborative Management Research (Shani et al. 2008) and Mohrman and Lawler's (2011) Useful Research: Advancing Theory and Practice.

The purpose of Academic-Practitioner Relationships is to provide a wealth of insights into collaborative relationships that generate both rigorous organizational research publications and benefit organizational performance. What is really helpful are accounts of the thought processes of the authors in illustrating how they conceptualize relationships and develop their own research capabilities over their journeys as researchers. I would say that the text is mainly relevant for business school academics because most of the authors are business school researchers. It is also intended for practitioners. The collection of 18 chapters illustrates the tensions, uncertainties and rich opportunities for impact in publishing and on organizational life through carrying out research in academic-practitioner dyads and teams. What I find particularly refreshing throughout are the vivid insights, many auto-ethnographic, into the trials and tribulations of the research journeys of leading management thinkers.

The key value proposition of this book is that 'organizational and management research should deliver the broadest value to society when theory and research are useful for improving organizational practice and the reality of practice truly informs theorizing' (Bartunek and McKenzie 2018, 1). Although the authors acknowledge resistance to this view, they argue that bridging the academic-practitioner or 'science-practice' gap divide represents a serious grand challenge (Banks et al. 2016) in modern society.

Academic-Practitioner Relationships is really helpful in conveying how it feels to occupy the gap in the middle between the academy and the world of practice, the angst and the ambiguity of adopting ambidextrous skills to develop theoretical insights and practical relevance. It is interesting that Bartunek and McKenzie (2018) prefer the metaphor 'interface' instead of 'gap' to capture academic-practitioner research as spaces for interactions and dialogue.

This book is particularly relevant for management scholars who are engaged with the impact agenda (e.g. Research Excellence impact case writers in the UK) and required to publish in international journals. It is also of interest to government policy-makers, organizations, research councils, professional bodies and business school associations that facilitate engagement between universities and practitioners, irrespective of whether there is push or pull from the academy or organizations. 
The collection of insights provides guidance through uncertainties for management scholars and action researchers to navigate complexities at the interface between theory and practice. In particular, the book is highly relevant for practitioner-scholars who are enrolled on doctoral programmes such as the DBA (Doctorate in Business Administration) or Executive Doctorate whose identities are changing into the roles of scholar-practitioner. The book does not teach consultancy skills but the middle section is a helpful reminder of the importance of developing constructive and humanizing collaborations.

While the book does not include examples of failed collaborations, it mentions unintended consequences. It offers recommendations on building positive academic-practitioner dynamics for research projects: willingness to transcend contradictions, differences in logics, temporal approaches, communications, interests, motivations, rigor, relevance, priorities which inevitably create paradoxes and tensions. The ability to appreciate opposing views simultaneously is essential. This requires capabilities in reframing identities, praxis, learning and coproduction despite contradictions in expectations and priorities, juggling being and going, intention and action. 'Arbitrage' (Van de Ven) is a key skill for the scholar who is engaged with practice, i.e. negotiating mutual benefits without harming stakeholders' key priorities.

The book is structured into 18 chapters and 3 parts focused on 'conceptual challenges', 'developing capabilities' and 'becoming and being at home in both worlds'. The final chapter is sole authored by the manager of Google's People Innovation Lab (PiLab) which provides perspectives on collaborations with university researchers and the integration of an incompany HR R\&D lab. There is no concluding chapter that looks forward to changes in the relationship between academics and practitioners.

Bartunek and McKenzie $(2018,1)$ aim to 'showcase the contemporary vitality of academicpractitioner relationships and partnerships and they suggest future steps.' This is underpinned by a key value proposition explored in the book:

As social scientists who focus on management and organizations our role is to deliver research that makes a positive difference to business, to an array of organizations and to the wider society. But this cannot be done except in partnership with ... practitioners.

While they acknowledge arguments resisting this world view (e.g. Daft and Lewin 2008), they note strong recent supportive arguments (e.g. Banks et al. 2016).

Part I conceptualizes academic-practitioner relationships philosophically based on perspectives from Aristotle (Nielson; Shani, Tenkasi and Alexander), Shamanism (Waddock) and contemporary theory (Coghlan). The first part is philosophical, theorizing the boundaries of productive academic-practitioner relationships, for example drawing on Aristotle's notion of phronesis, practical wisdom that combines theory and practice, which was extended by Cant, Hume, Kant and Popper. Coghlan links insights on experience, understanding and judgement in the process of knowing from the philosopher Bernard Lonergan with Reg Revans' work on action learning and self-reflection. Coghlan focuses on 'metalogue' in structuring group discussions around big questions and processes to generate insights from both practitioners and academics. Nielsen underlines the salience of individuals' reflexivity through inductive attention to data based on experience, interpretations based on theories, ethical action, developing ethical practices, learning and building theory rather than academic-practitioner relationships solely focusing on rigid techniques. Adam Curle, a British academic and Quaker peace activist, is cited as an exemplar of a successful mediator and reflector-in-practice who developed strong empathy with his practitioner collaborators. Waddock compares academics with intellectual shamans who ask big questions, look at things holistically and behave as healers, networking, engaging in scholarship and learning about ambiguities and paradoxes across borders between academics and practitioners. Bartunek and Rynes provide an interesting analysis of 
empirical articles on academic-practitioner relationships that revealed five storylines: discrepancies in priorities and values; contact stories about how collaborations improve academic findings and citations; narratives about cultural differences that generate tensions; stories about practitioner journals impacting academics more than academic papers influencing practitioners. This analysis has implications for identities and identity work and the dualities of differences and similarities.

Part II of the book focuses on skills development in theory-practice linkages, with capabilities in flipping the classroom to facilitate workshops on engaged scholarship (Van de Ven), working within paradoxes (Jarzabkowski, Lewis and Smith), 'creative action' (MacLean and Maclntosh), on DBA programmes (Collins and McBain) and developing praxis (Antonacopolou). The second part highlights developing professional research capabilities over extended periods of time in faculty and doctoral education to enable collaborations with practitioners. Researchers need to be human, develop skills in arbitrage, navigate paradoxes and tensions, communicate empathetically the value and meaning of their research with researchers without alienating others with academic terminology, facilitate 'generative dialogue', and be prepared for challenges to their own identities and limits while developing trust and mutual understanding in interdependent relationships across the worlds of the academy and practice.

A common theme throughout the book is the human qualities (empathy rather than just dehumanized techniques) of academic researchers and practitioners to address complex modern challenges and to enhance social and economic well-being. The theme of research professionalism allows for surprises, emotions, intuition complements rational, systematic, rigorous and scientific research. The skill of arbitrage is advocated, the 'strategy of explaining differences by seeing the interdependencies and webs of entanglement between different and divergent dimensions of a problem, its boundaries and context' (Van de Ven 2007, 15). Van de Ven believes that both academics and practitioners need to hone their skills in dealing with problems together that are too complex to manage in isolation. He provides online access to a free module on engaged scholarship: z.umn.edu/mgmt8101. Antonacopoulou stresses the importance of curiosity, conscience, positive virtues, confidence building and trust to build phronesis. In the middle part of this book, the space between academics and practitioners is explored where tensions in interests, logics, styles, communications, motivations play out and multiple, contradictory agendas are explored. Jarzabkowski and her colleagues explore the paradoxical mind-set of differentiating and integrating practices. In another chapter, Collins and McBain discuss how DBA students as apprentice researchers are socialized.

MacLean and Maclntosh's chapter on 'Reconceptualizing "action" in action research' in the second section of the book on developing capabilities merits special attention in this book review for this journal focused on research and practice in action learning. In their auto-ethnographic piece, the two Scottish researchers define 'academic professionalism' within action research studies in collaborating with practitioners. Ironically, they conclude that 'creative action' reveals that good research incorporates aspects of 'unprofessional research.' This includes 'conflict, contestability, and unpredictability' (Maclntyre 1998, 65).

Entering the field originally with rational mind sets based on their training in the natural scientists, the co-authors discover that they are never fully in charge of their social science research. They come to realize that they must 'rehumanize' their approach with an appreciation of embodying their research. In their chapter, MacLean and Maclntosh iterate between their reflections at the university ranch and experiences in the field. Gradually, the pair starts to understand their management research in the field through the lens of complexity theory, with emergent properties, dynamic and unpredictable. Subsequently, they moved beyond systems to a focus on 'the actions of human beings - with their unruly emotions, disturbing 
idiosyncrasies, biographies, and, perhaps most unnerving of all for a couple of "techies," interacting human bodies' (MacLean and Maclntosh 2018, 147).

This chapter by MacLean and Maclntosh is helpful in reassuring the (novice) action researcher that when research projects do not follow initial logical plans, 'creative action' and reflections are informed by poetry, art, and aesthetics, creative dialogue (Shotter 2008) and political, even mysterious, dynamics, with researchers acting as both story-makers and story tellers. In their experiences, interactive sense-making is enabled by the three pragmatic dimensions of creative action: emerging intention, embodied expression and interactive identity formation (based on Joas 1996). This is an also excellent reference chapter for STEM (science, technology, engineering, mathematics) students who are new to social science research and perplexed by having to engage in 'generative dialogic encounters' (Joas 1996, 151) based on the action researcher engaging with human emotions, intuition, paradoxes, personalities, hunches and human creativity in interactions.

Finally, Part III of the book presents seven cases of academics collaborating with practitioners and a final case of Google's HR R\&D Lab that commissions research collaborations with university researchers to exemplify the diversity of practices globally. Empson's auto-ethnographic account of liminality powerfully conveys the fixation in the UK system on 'REFability', i.e. whether an academic member of faculty has published sufficient quality journals articles to be submitted to the Research Excellence Framework (REF), the national research evaluation exercise. She recounts how her extensive work with practitioners resulted in her being 'non-REFable'. She explains painfully, 'my 20 years of scholarly endeavour had been reduced to a single number, my REF score ... Within a short space of time, I shifted from being a star performer to a "question mark"' (Empson 2018 , 209). Empson recovered her research productivity by disengaging from her work with practice. Subsequently, as an Independent Non Executive of KPMG UK, she restored her links with practice which boosted her research.

Other cases in the final part of this book include the Center for Effective Organizations (CEO) at the University of Southern California, collaboration between the Network for Business Sustainability in South Africa and the South Africa Food Lab with its focus on knowledge transformation, Knowledge Transfer Partnerships in Essex University in the UK, the Henley Forum. Carton and Dameron typologize examples of collaborative interfaces which have resulted in significant organizational impacts.

The book is very much about personal journeys of discovery at the interface and the importance of sustaining mutually beneficial relationships between management academics and practitioners. Academic-Practitioner Relationships, however, lacks voices from a range of developing countries or Asia. There is no concluding chapter that discusses future scenarios. It would be interesting to include further chapters that are sole authored or with the lead author coming from practice. There is a bias in the text with the viewpoints of university academics dominating. It would also be helpful to engage policy-makers and representatives from professional and business school associations on how national and institutional infrastructures are resourced and configured to enable collaborative research with practitioners and incentives for this. A companion web site of interviews, podcasts, videos and back stories about institutional constraints, failed collaborations and capturing reflections during a live project would be interesting. Exemplars for DBA students on making the transition from practitioner-scholar to scholar-practitioner and evidencing theoretical, personal, professional and practical organizational impacts would also be interesting to incorporate into DBA workshops.

Overall, in the context of an increasing government research evaluation policy focus on measuring the wider societal benefits of academic research in particular parts of the world (e.g. Australia, the UK), Bartunek and McKenzie's co-edited text on academic-practitioner relationships is very helpful. It follows in the genealogy of two highly influential books 
published in the preceding two decades in the USA: Ernest Boyer's Scholarship Reconsidered published in 1990 and Andy Van de Ven's text Engaged Scholarship published in 2007. Bartunek and McKenzie's edited book extends these works by practising what it preaches - through international collaborations that include the voices of practitioners, consultants and women, with two of the 18 chapters co-authored by academic-practitioner teams. In light of the 2017 Academy of Management report on scholarly impact (Haley et al. 2017), this book represents an inspiring collection of insights into the diversity of ways globally to achieve worthwhile scholarly impact with practitioners and on management practice.

\section{References}

Banks, G. C., J. M. Pollack, J. E. Bochantin, B. L. Kirkman, C. E. Whelpley, and E. H. O'Boyle. 2016. "Management's Science-Practice Gap: A Grand Challenge for All Stakeholders." Academy of Management Journal 59 (6): 2205-22031.

Boyer, E. 1990. Scholarship Reconsidered: Priorities of the Professoriate. The Carnegie Foundation for the Advancement of Teaching. New York: Wiley.

Daft, R. L., and A. Y. Lewin. 2008. "Rigor and Relevance in Organization Studies: Idea Migration and Academic Journal Evolution." Organization Science 19 (1): 177-183.

Empson, L. 2018. "My Liminal Life: Perpetual Journeys Across the Research Practice Divide." In AcademicPractitioner Relationships: Developments, Complexities and Opportunities, edited by J. Bartunek, and J. McKenzie, 200-216. Abingdon: Routledge.

Haley, U. C. V., M. C. Page, T. S. Pitsis, J. L. Rivas, and K. F. Yu. 2017. Measuring and Achieving Scholarly Impact: A Report from the Academy of Management's Practice Theme Committee. New York: Academy of Management.

Joas, H. 1996. The Creativity of Action. Chicago, IL: University of Chicago Press.

Maclntyre, A. C. 1998. "Social Science Methodology as the Ideology of Bureaucratic Authority." In The Maclntyre Reader, edited by K. Knight, 53-68. Cambridge: Polity Press.

MacLean, D., and R. Maclntosh. 2018. "Is There Anybody in There? Reconceptualizing 'Action' in Action Research." In Academic-Practitioner Relationships: Developments, Complexities and Opportunities, edited by J. Bartunek, and J. McKenzie, 142-158. Abingdon: Routledge.

Mohrman, S. A., and E. E. Lawler2011. Useful Research: Advancing Theory and Practice. San Francisco, CA: BerrettKoehler.

Shani, A. B. R., S. A. Mohrman, W. A. Pasmore, B. Stymne, and N. Adler2008. Handbook of Collaborative Management Research. Thousand Oaks, CA: Sage.

Shotter, J. 2008. "Dialogism and Polyphony in Organizing Theorizing in Organization Studies: Action Guiding Anticipations and the Continuous Creation of Novelty." Organization Studies 29 (4): 501-524.

Van de Ven, A. H. 2007. Engaged Scholarship: A Guide for Organizational and Social Research. Oxford: Oxford University Press.

Julie Davies

Huddersfield Business School, University of Huddersfield, Queensgate, Huddersfield HD1 3DH, UK Q j.a.davies@hud.ac.uk

(C) 2018 Julie Davies

https://doi.org/10.1080/14767333.2018.1510628

Check for updates

\section{Action learning in health, social and community care principles, practice and resources, edited by John Edmonstone, Abingdon, UK, CRC Press, Taylor \& Francis Group, 2018, 197 pp., £34.70 (paperback), ISBN-13: 978-1-138-03559-1}

This book is a welcome addition into the developing practice of action learning across health, social and community care. Edmonstone's previous book on Action Learning in Healthcare (2011) was a helpful introduction into the application of action learning for health services 